\title{
DETERMINATION OF RADIONUCLIDES IN SOIL FROM BARENDRA REGION IN RAJSHAHI AND MINING REGION IN DINAJPUR
}

\author{
M Matiur Rahman ${ }^{1}$, Aleya Begum ${ }^{2}$, Mst. Jannatul Ferdous ${ }^{2} *$ and M Aminul Islam ${ }^{1}$ \\ ${ }^{1}$ Department of physics, University of Rajshahi, Rajshahi, Bangladesh. \\ ${ }^{2}$ Health Physics Division, Atomic Energy Centre (AEC), Dhaka, Bangladesh \\ * Corresponding author: ferdous28@yahoo.com
}

\begin{abstract}
The level of natural radioactivity in soil samples calculated from the Barendra region, Rajshahi and the Mining region, Dinajpur was measured and the radiological hazard parameters in both the regions were estimated. The activity concentrations of naturally occurring radioactive materials in the ${ }^{238} \mathrm{U}$ and ${ }^{232} \mathrm{Th}$ decay chains and in ${ }^{40} \mathrm{~K}$ were determined by means of a gamma-ray spectrometry system using an HPGe detector in a low background configuration at Atomic Energy Centre, Dhaka. The activity concentrations of ${ }^{238} \mathrm{U},{ }^{232} \mathrm{Th}$ and ${ }^{40} \mathrm{~K}$ found in the present study are compared with the reported values of the Northern region and other districts of Bangladesh and those of other countries of the world. Radiological hazard parameters of the two regions were estimated and compared with the world averages. The natural radioactivity in the Barendra and Mining region poses no threat to general public there. Artificial radionuclide ${ }^{137} \mathrm{Cs}$ was not found in the soil samples studied.
\end{abstract}

(Keywords: Radioactivity, HPGe Detector, Soil, Barendra and Mining region, Radiological hazard parameters)

\section{INTRODUCTION}

Radionuclides are the sources of radioactivity and emit nuclear radiations which have become a part of our daily lives. The majority of naturally occurring radionuclides belong to the radionuclides in the ${ }^{238} \mathrm{U}$ and ${ }^{232} \mathrm{Th}$ series, and the single decay radionuclide, ${ }^{40} \mathrm{~K}$ [1]. According to the National Council on Radiation Protection and Measurements Report, the most significant source of radiation exposure to humans is due to natural radiation in the environment [2]. This exposure to naturally occurring radiation also accounts for up to $85 \%$ of annual exposure dose received by the world population and any dose of radiation involves a possible risk to human health [3].

In order to protect the general public health against the radiation risk originating from Naturally Occurring Radioactive Material, the measurement of radioactivity in the environment needs to be considered to assess the biological effect on the human. This has also become the focus of greater attention by the IAEA in recent years [4]. The activity concentrations of ${ }^{238} \mathrm{U},{ }^{232} \mathrm{Th}$ and ${ }^{40} \mathrm{~K}$ and their progeny present in soil are measured in many countries of the world [5] including Bangladesh in order to monitor radiation level in the environment. Dinajpur is a district in Northern Bangladesh and located at the latitude and longitude coordinates of $25^{\circ} 33^{\prime} \mathrm{N}$ and $88^{\circ} 43^{\prime} \mathrm{E}$ (Figure 1).
There are sites of coal mine and stone mine at a distance of $40 \mathrm{~km}$ from the town. Coals are the major sources of radioactive materials released to the environment and coal combustion is more hazardous to health. Some regions in the Rajshahi District are called Barendra region and located at the latitude and longitude coordinates of $24^{\circ} 26^{\prime} 14 \mathrm{~N}$ and $88^{\circ} 36^{\prime} 59 \mathrm{E}$ (Figure 1). It is in the Northwest part of Bangladesh. Main rivers are the Padma, the Mahananda, the Baral and the Barnai. So, it is highly possible to suffer from radioactivity due to situation of the source of the rivers in India.

Also the large number of agricultural activities, high demand for utilization of fertilizers may give rise to enhancement in the level of background radioactivity in particular areas. As these have different geological characteristics, we planned to examine the activity concentrations of the soil of the Mining region of Dinajpur and Barendra region of Rajshahi.

The present study has been carried out to evaluate the level of radioactivity due to ${ }^{238} \mathrm{U},{ }^{232} \mathrm{Th}$ and ${ }^{40} \mathrm{~K}$ in soil samples collected from the Barendra region of Rajshahi and the Mining region of Dinajpur. The aim of this research not only the determination of natural radioactivity in soil samples but also the determination of the radiological hazard parameters such as Gamma Dose Rate (D), Radium Equivalent Activity $\left(\mathrm{Ra}_{\mathrm{eq}}\right)$, External Hazard Index $\left(\mathrm{H}_{\mathrm{ex}}\right)$ and Annual Effective Dose Equivalent $\left(D_{\text {eff }}\right)$ for individuals living in both regions. 


\section{MATERIALS AND METHODS}

Sample Collection and Preparation: In 2012, total 22 Soil samples were collected in the selected sites of Barendra region (Godagari, Rajshahi) and Mining region (Dinajpur) in the northern part of Bangladesh separately (11 samples from Barendra Region and other 11 samples from Mining Region). All samples were carefully collected at $5 \mathrm{~cm}-10 \mathrm{~cm}$ depth from the soil-surface in agriculture land by using shovel and each of the samples weighed approximately $1 \mathrm{~kg}$. At the laboratory of Health physics Division in Atomic Energy Center Dhaka, the collected samples were transferred from the polyethylene bags to the acetone-cleaned stainless steel bucket and a crowbar was used to break the big soil stone separately. Then the samples were dried at $105^{\circ} \mathrm{C}$ until a constant weight was achieved and it was ensured that any significant moisture was removed from the samples. Each of the dried samples was grounded to fine powder in an agate motor separately. The powdered samples were then sieved using a fine aperture mesh screen (mesh size $2 \mu \mathrm{m}$ ) in order to remove extraneous items like plant material, roots, pebbles etc. and to obtain a fine grained sample that would present a uniform matrix to the detector. Finally each of the grounded samples was transferred to cylindrical plastic-container $(7.3 \mathrm{~cm}$ diameter $\times 8.9 \mathrm{~cm}$ height). The containers were then labeled properly and sealed tightly, rapped with thick vinyl tapes around their screw necks. The samples were stored for at least four weeks before counting in order to attain secular equilibrium.
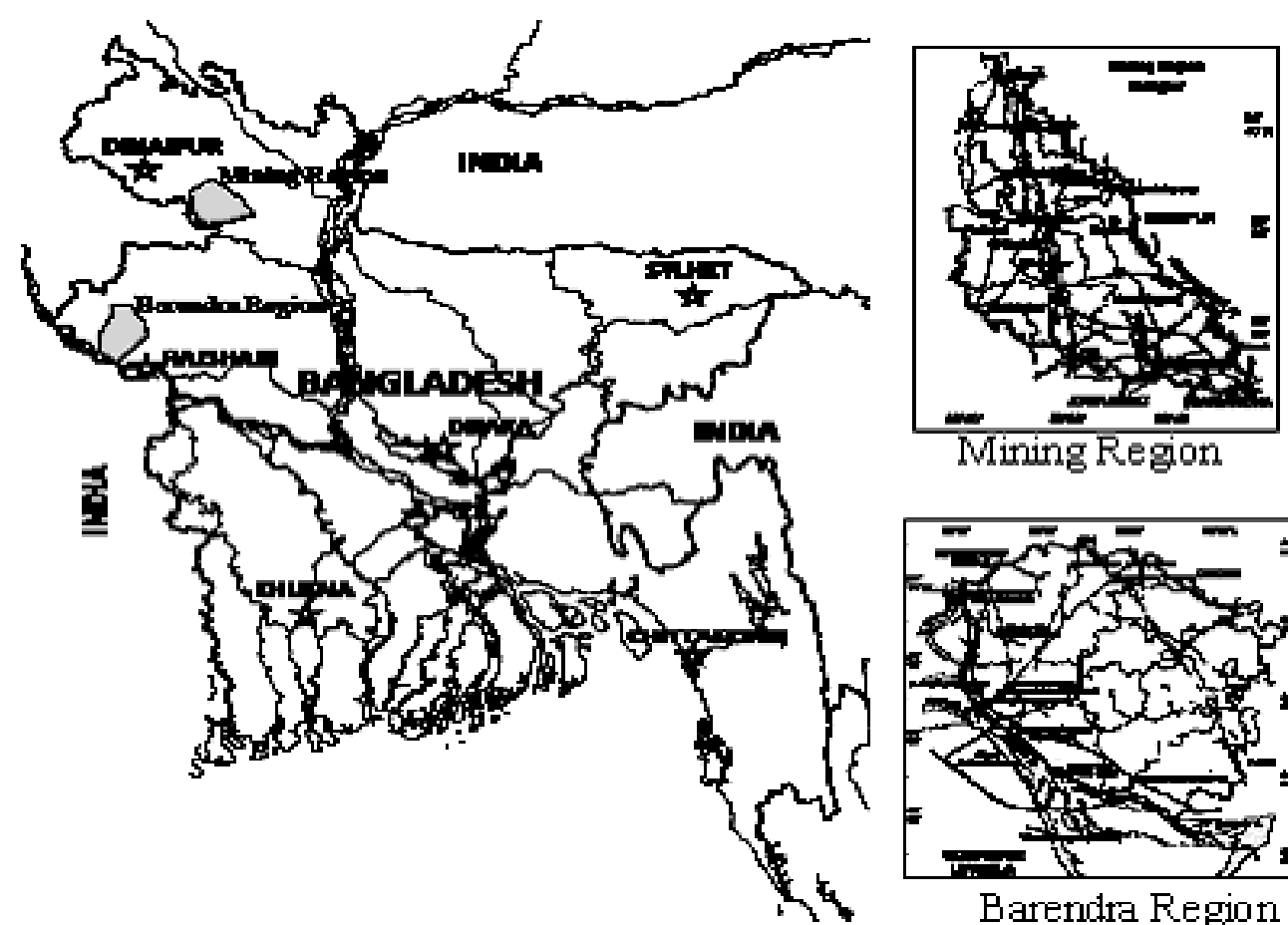

Figure 1. Map of the sample location in Bangladesh.

\section{Measurement procedures and Data Analysis:}

The activity concentration of gamma ray emitting radioisotopes in the samples were measured by using a gamma ray spectrometer with a highresolution HPGe coaxial detector coupled with a Silena Emcaplus multichannel analyzer (MCA). The effective volume of the detector was 83.469 $\mathrm{cm}^{3}$ and energy resolution of the $1.33 \mathrm{MeV}$ energy peak for ${ }^{60} \mathrm{Co}$ was found as $1.69 \mathrm{keV}$ at full width half maximum (FWHM) with a relative efficiency of $19.6 \%$.The Ge-detector was cooled with a liquid nitrogen cryostat to reduce the leakage current.

The detector was enclosed with a cylindrical lead shield to reduce the background radiation from various natural radiation sources and to isolate from other radiation sources used in nearby surroundings. All samples were counted for 5000s. The peaks identified in Figures.2 (a) and (b) are 
due to $\mathrm{Pb}^{212}(238.6 \mathrm{keV}), \mathrm{Pb}^{214}(295.2 \mathrm{keV}), \mathrm{Pb}^{214}$ (351.9keV), $\mathrm{Tl}^{208}(583.1 \mathrm{keV}), \mathrm{Bi}^{214}(609.3 \mathrm{keV})$, $\mathrm{Ac}^{228} \quad(911.2 \mathrm{keV}), \quad \mathrm{Ac}^{228} \quad(968.9 \mathrm{keV}), \quad \mathrm{Bi}^{214}$ $(1120.2 \mathrm{keV})$ and ${ }^{40} \mathrm{~K}(1460.8 \mathrm{keV})$. No ${ }^{137} \mathrm{Cs}$ line was obtained at $661.66 \mathrm{keV}$. The activity concentration of individual radionuclides was calculated from the following equation [6]:

$$
A\left(B q k g^{-1}\right)=\frac{N}{P_{\gamma} \times \varepsilon \times W}
$$

Where $\mathrm{A}$ is the activity concentration of each radio-nuclide in the sample, $\mathrm{N}$ is the net count of each radio-nuclide which is found by subtracting the sample radio-nuclide activity counting from background activity counting, $\varepsilon$ is the detector efficiency of the specific $\gamma$ ray, $\mathrm{P} \gamma$ is the transition probability of the specific $\gamma$ ray and $\mathrm{W}$ is the mass of the sample $(\mathrm{kg})$. Error associated with every calculation was measured by standard deviation equation.

The activity concentrations of ${ }^{238} \mathrm{U}$ and ${ }^{232} \mathrm{Th}$ were determined from the average concentration of nuclides $\left[\mathrm{Pb}^{214}(295.2 \mathrm{keV}), \mathrm{Pb}^{214}(351.9 \mathrm{keV}), \mathrm{Bi}^{214}\right.$ $(609.3 \mathrm{keV})$ and $\left.\mathrm{Bi}^{214}(1120.2 \mathrm{keV})\right]$ and $\left[\mathrm{Pb}^{212}\right.$ $(238.6 \mathrm{keV}), \quad \mathrm{Tl}^{208}(583.1 \mathrm{keV}), \quad$ and $\mathrm{Ac}^{228}$ (911.2keV), $\left.\mathrm{Ac}^{228}(968.9 \mathrm{keV})\right]$ respectively. The activity concentrations of ${ }^{40} \mathrm{~K}$ were determined directly by measurement of the gamma-ray transitions at $1460.8 \mathrm{keV}$. Error associated with every calculation was measured by standard deviation equation.

Radiological hazard parameters: The radiological hazard parameters are calculated from the measured activity concentrations of the radionuclides ${ }^{238} \mathrm{U},{ }^{232} \mathrm{Th}$ and ${ }^{40} \mathrm{~K}$ in soil samples. Due to a non uniform distribution of natural radionuclides in the soil samples, the actual activity level of ${ }^{226} \mathrm{Ra}\left({ }^{238} \mathrm{U}\right),{ }^{232} \mathrm{Th}$ and ${ }^{40} \mathrm{~K}$ in the samples can be evaluated by means of a common radiological index named the Radium Equivalent Activity $\left(\mathrm{Ra}_{\mathrm{eq}}\right)$. It is the most widely used index to assess the radiation hazards and was calculated using following equation [5]:

$$
R a_{e q}\left(B q . \mathrm{kg}^{-1}\right)=C_{R a}+1.43 C_{T h}+0.077 C_{K}
$$

Where, $\mathrm{C}_{\mathrm{Ra}}, \mathrm{C}_{\mathrm{Th}}$ and $\mathrm{C}_{\mathrm{K}}$ are the activity concentrations of ${ }^{226} \mathrm{Ra}\left({ }^{238} \mathrm{U}\right),{ }^{232} \mathrm{Th}$ and ${ }^{40} \mathrm{~K}$ in Bq. $\mathrm{kg}^{-1}$, respectively.

In order to assess any radiological hazard, the exposure to radiation arising from radionuclides present in soil can be determined in terms of many parameters. A direct connection between radioactivity concentrations of natural radionuclides and their exposure is known as the absorbed dose rate in the air at 1 metre above the ground surface.

The mean activity concentrations of ${ }^{226} \mathrm{Ra}\left({ }^{238} \mathrm{U}\right)$, ${ }^{232} \mathrm{Th}$, and ${ }^{40} \mathrm{~K}\left(\mathrm{~Bq} \cdot \mathrm{kg}^{-1}\right)$ in the soil samples are used to calculate the absorbed dose rate given by the following

[7]:

$$
D\left(n G y \cdot h^{-1}\right)=0.462 C_{R a}+0.604 C_{T h}+0.0417 C_{K}
$$

To limit the radiation exposure attributable to natural radionuclides in the samples to the permissible dose equivalent limit of $1 \mathrm{mSv} \cdot \mathrm{y}^{-1}$, the

$$
H_{e x}=\left(\frac{C_{R a}}{370}\right)+\left(\frac{C_{T h}}{259}\right)+\left(\frac{C_{K}}{4810}\right)
$$

In order to keep the radiation hazard insignificant, the value of external hazard index must not exceed the limit of unity. The maximum value of $\mathrm{H}_{\mathrm{ex}}$ equal to unity corresponds to the upper limit of radium equivalent activity 370 Bq. $\mathrm{kg}^{-1}$ [24]. external hazard index was calculated using the following formula [5]:

The absorbed dose rate in air at 1metre above the ground surface does not directly provide the radiological risk to which an individual is exposed. The absorbed dose can be considered in terms of the annual effective dose equivalent from outdoor terrestrial gamma radiation which is converted from the absorbed dose by taking into account two 
factors, namely the conversion coefficient from absorbed dose in air to effective dose and the outdoor occupancy factor.
The annual effective dose equivalent can be estimated using the following formula [7]:

$$
D_{e f f}\left(\mu S v \cdot y^{-1}\right)=D\left(n G y \cdot h^{-1}\right) \times 8760 h \times 0.2 \times 0.7 S v \cdot G y^{-1} \times 10^{-3}
$$

The values of those parameters used in the

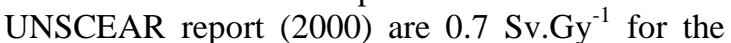
conversion coefficient from absorbed dose in air to effective dose received by adults and $0.2 \mathrm{~Sv}^{-G_{y}}{ }^{-1}$ for the outdoor occupancy factor.

\section{RESULTS AND DISCUSSION}

The activity concentrations of ${ }^{238} \mathrm{U},{ }^{232} \mathrm{Th}$ and ${ }^{40} \mathrm{~K}$ for different soil samples of Barendra and Mining regions are presented in Table 1. For Barendra region soil samples, it is found that the activity concentration of ${ }^{238} \mathrm{U}$ ranges from $31.9 \pm 1.3$ to $42.7 \pm 1.4 \mathrm{~Bq} \cdot \mathrm{kg}^{-1}$ with mean $36.7 \pm 1.4 \mathrm{~Bq} \cdot \mathrm{kg}^{-1}$, activity concentration of ${ }^{232} \mathrm{Th}$ ranges from $52.9 \pm 1.6$ to $68.9 \pm 1.7 \mathrm{~Bq} \cdot \mathrm{kg}^{-1}$ with mean $59.7 \pm 1.7$
Bq. $\mathrm{kg}^{-1}$, activity concentration of ${ }^{40} \mathrm{~K}$ ranges from $232.5 \pm 2.3$ to $320.6 \pm 2.4 \mathrm{~Bq} \cdot \mathrm{kg}^{-1}$ with mean $282.5 \pm 2.3 \mathrm{~Bq} \cdot \mathrm{kg}^{-1}$.

For Mining region soil samples, activity concentration of ${ }^{238} \mathrm{U}$ ranges from $31.3 \pm 1.3$ to $48.3 \pm 1.5$ Bq. $\mathrm{kg}^{-1}$ with mean $37.1 \pm 1.4$ Bq. $\mathrm{kg}^{-1}$, activity concentration of ${ }^{232} \mathrm{Th}$ ranges from $44.5 \pm 1.5$ to $81.9 \pm 1.9 \mathrm{~Bq} \cdot \mathrm{kg}^{-1}$ with mean $56.9 \pm 1.7$ $\mathrm{Bq} / \mathrm{kg}$, activity concentration of ${ }^{40} \mathrm{~K}$ ranges from $222.0 \pm 2.3$ to $475.7 \pm 2.5 \mathrm{~Bq} \cdot \mathrm{kg}^{-1}$ with mean $343.7 \pm 2.4 \mathrm{~Bq} \cdot \mathrm{kg}^{-1}$. It is found that the mean values of ${ }^{238} \mathrm{U}$ and ${ }^{232} \mathrm{Th}$ concentrations are similar for both the regions. The mean of ${ }^{40} \mathrm{~K}$ concentration in Mining region is higher than that in Barendra region.

Table 1. Activity concentrations of ${ }^{238} \mathrm{U},{ }^{232} \mathrm{Th}$ and ${ }^{40} \mathrm{~K}$ in soil samples of Barendra region and Mining region.

\begin{tabular}{|c|c|c|c|c|}
\hline \multirow{2}{*}{ Location } & \multirow{2}{*}{$\begin{array}{c}\text { Sample } \\
\text { codes }\end{array}$} & \multicolumn{3}{|c|}{ Average activity concentration in Bq.kg ${ }^{-1}$} \\
\hline & & ${ }^{238} \mathbf{U}$ & ${ }^{232} \mathrm{Th}$ & ${ }^{40} \mathbf{K}$ \\
\hline \multirow{11}{*}{ 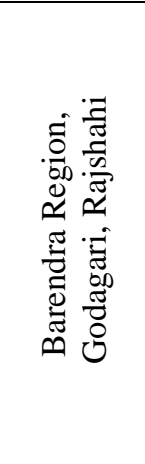 } & RGMM & $42.7 \pm 1.4$ & $68.1 \pm 1.7$ & $232.5 \pm 2.3$ \\
\hline & RGSM & $31.9 \pm 1.3$ & $52.9 \pm 1.6$ & $253.7 \pm 2.3$ \\
\hline & RGCB & $35.6 \pm 1.4$ & $56.8 \pm 1.7$ & $253.7 \pm 2.3$ \\
\hline & RGDG & $33.4 \pm 1.3$ & $54.2 \pm 1.6$ & $320.6 \pm 2.4$ \\
\hline & RGKH & $37.5 \pm 1.4$ & $57.9 \pm 1.7$ & $306.5 \pm 2.4$ \\
\hline & RGAT & $38.3 \pm 1.4$ & $68.9 \pm 1.8$ & $306.5 \pm 2.4$ \\
\hline & RGBP & $35.4 \pm 1.4$ & $55.6 \pm 1.7$ & $296.0 \pm 2.4$ \\
\hline & RGJB & $34.9 \pm 1.4$ & $62.8 \pm 1.7$ & $285.4 \pm 2.4$ \\
\hline & RGBM & $40.2 \pm 1.4$ & $57.4 \pm 1.7$ & $246.6 \pm 2.3$ \\
\hline & RGKP & $37.0 \pm 1.4$ & $65.4 \pm 1.7$ & $292.4 \pm 2.4$ \\
\hline & RGMD & $37.3 \pm 1.4$ & $56.9 \pm 1.7$ & $313.6 \pm 2.4$ \\
\hline \multicolumn{2}{|c|}{ Mean } & $36.7 \pm 1.4$ & $59.7 \pm 1.7$ & $282.5 \pm 2.4$ \\
\hline \multirow{11}{*}{ 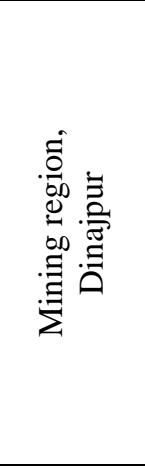 } & DFSA & $37.3 \pm 1.4$ & $59.6 \pm 1.7$ & $243.1 \pm 2.3$ \\
\hline & DFTP & $42.4 \pm 1.5$ & $47.6 \pm 1.6$ & $475.7 \pm 2.5$ \\
\hline & DFCP & $38.6 \pm 1.4$ & $55.9 \pm 1.6$ & $352.3 \pm 2.4$ \\
\hline & DPCM & $48.3 \pm 1.5$ & $81.9 \pm 1.9$ & $222.0 \pm 2.3$ \\
\hline & DPSM & $31.3 \pm 1.3$ & $51.0 \pm 1.6$ & $250.2 \pm 2.3$ \\
\hline & DPVP & $33.8 \pm 1.3$ & $56.6 \pm 1.7$ & $296.0 \pm 2.4$ \\
\hline & DHHL & $29.5 \pm 1.3$ & $53.0 \pm 1.6$ & $377.0 \pm 2.4$ \\
\hline & DBSA & $36.5 \pm 1.4$ & $59.7 \pm 1.7$ & $454.5 \pm 2.5$ \\
\hline & DBJN & $32.5 \pm 1.3$ & $44.5 \pm 1.5$ & $429.9 \pm 2.5$ \\
\hline & DNSP & $34.9 \pm 1.4$ & $57.4 \pm 1.7$ & $377.0 \pm 2.4$ \\
\hline & DNSA & $43.0 \pm 1.4$ & $58.2 \pm 1.7$ & $303.0 \pm 2.4$ \\
\hline \multicolumn{2}{|c|}{ Mean } & $37.1 \pm 1.4$ & $56.9 \pm 1.7$ & $343.7 \pm 2.4$ \\
\hline
\end{tabular}




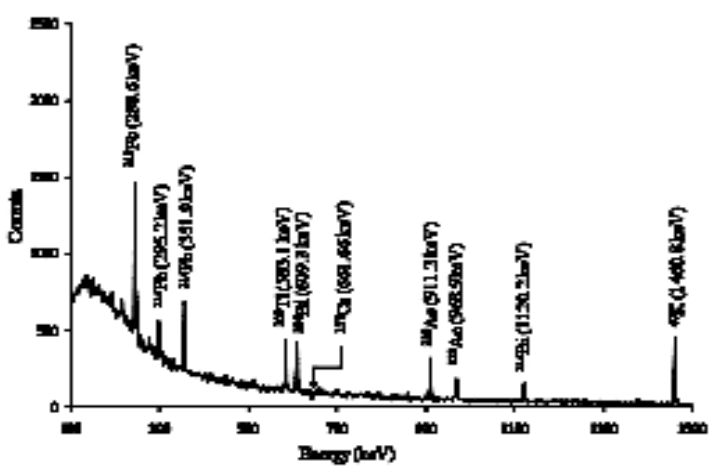

(a)

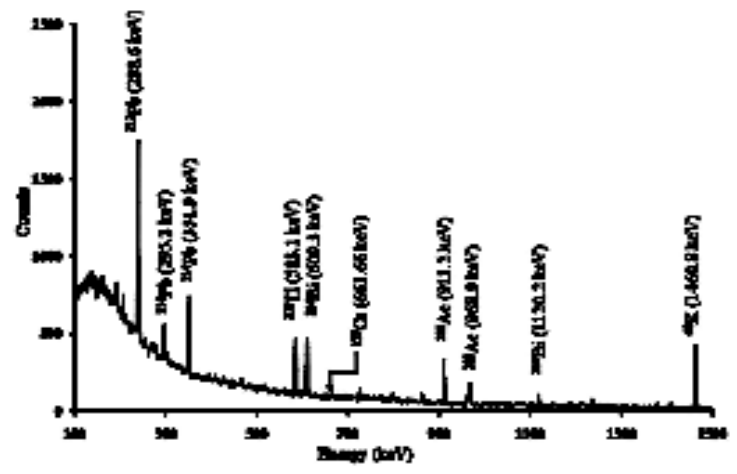

(b)

Figure 2. Spectrum of the gamma-rays from (a) one soil sample (sample code RGMM) of Barendra region and (b) one soil sample (sample code DPCM) of Mining region.

The radionuclide concentrations in the soil samples of the two regions are presented along with those of other places in Bangladesh in Table 2. The results of the present study are compared with those of the northern region at first. The ${ }^{238} \mathrm{U}$ and ${ }^{232} \mathrm{Th}$ concentrations of Rajshahi Barendra region and Dinajpur Mining region are about 2.5 times less than the high radioactivity zones of Rangpur, Lalmonirhat and Kurigram [8]. The ${ }^{40} \mathrm{~K}$ activity concentration of the former is about 6 times less than the latter.

Thus, the high radioactivity zone seems to be localized. ${ }^{238} \mathrm{U}$ content in the two regions is comparable with the values of other districts in Bangladesh except that in Sylhet where the value is about $50 \%$ higher. ${ }^{232} \mathrm{Th}$ content in most of the districts are almost similar to these in the two regions except that in Sylhet and Kuakata Sea Beach where the values are $\approx 110 \%$ and $50 \%$ higher respectively. The concentrations of ${ }^{40} \mathrm{~K}$ in these two regions are much lower than the values in all other districts. No peak of man-made fission fragment ${ }^{137} \mathrm{Cs}(661.66 \mathrm{keV})$ was observed in the gamma-ray spectrum. It may be concluded that there is no ${ }^{137} \mathrm{Cs}$ radionuclide in the soil samples under study. However, it may be stated that the ${ }^{137} \mathrm{Cs}$ activity was beyond the detection limit of $1.54 \mathrm{~Bq}$ in our measurement system.

It seems that there is fresh nuclear fallout in the region studied. The average activity concentrations of ${ }^{238} \mathrm{U},{ }^{232} \mathrm{Th}$ and ${ }^{40} \mathrm{~K}$ of the two regions are shown along with the values of other countries in Table 3. The ${ }^{238} \mathrm{U}$ concentrations in both regions are comparable with these of most of other countries of the world. In fact, the averages of these two regions are roughly equal to the world average. The ${ }^{232} \mathrm{Th}$ concentrations of the two regions, on the other hand, are higher than those of most other countries and are almost double the world average. The ${ }^{40} \mathrm{~K}$ concentrations of the two regions are smaller than the values of most countries and about $25 \%$ lower than the world average.

The values of the radiological hazard parameters are shown in Table 4. The Radium Equivalent Activity $\mathrm{Ra}_{\mathrm{eq}}$ ranges from 125.2 to $158.3 \mathrm{~Bq} \cdot \mathrm{kg}^{-1}$ with mean $141.9 \mathrm{~Bq} \cdot \mathrm{kg}^{-1}$ for the Barendra region soil samples and ranges from 121.8 to $180.9 \mathrm{~Bq} \cdot \mathrm{kg}^{-}$ ${ }^{1}$ with mean $142.5 \mathrm{Bqkg}^{-1}$ for the Mining region soil samples. It is found that the $\mathrm{Ra}_{\mathrm{eq}}$ values for all soil samples in the present work are lower than the accepted safety limit value of $370 \mathrm{~Bq} \cdot \mathrm{kg}^{-1}$ as recommended by the Organization for Economic Cooperation and Development (OECD) [9]. The values are graphically shown in Fig 3(a).

The estimated Absorbed Dose Rate D based on soil radioactivity ranges from 61.4 to $72.2 \mathrm{nGy}^{-1} \mathrm{~h}^{-1}$ with a mean value $64.9 \mathrm{nGy} \cdot \mathrm{h}^{-1}$ for the Barendra region soil samples and ranges from 55.8 to $81.1 \mathrm{nGy} \cdot \mathrm{h}^{-1}$ with mean $65.9 \mathrm{nGy} \cdot \mathrm{h}^{-1}$ for the Mining region soil samples. These values are slightly greater than the worldwide mean value $60 \mathrm{nGy} \cdot \mathrm{h}^{-1}$ [9]. The comparison is shown in Fig 3(b).

As listed in Table 4, the calculated values of the External Hazard Index $\mathrm{H}_{\mathrm{ex}}$ vary from 0.34 to 0.43 and the average value is found to be 0.39 for the Barendra region and vary from 0.33 to 0.49 and the average value is found to be 0.39 for the Mining region. 
Table 2. Comparison of average activity concentration of ${ }^{238} \mathrm{U},{ }^{232} \mathrm{Th}$ and ${ }^{40} \mathrm{~K}$ in soil samples of different regions within Bangladesh.

\begin{tabular}{|c|c|c|c|}
\hline \multirow{2}{*}{ Locations } & \multicolumn{3}{|c|}{ Average activity concentration in $\mathrm{Bq} \cdot \mathrm{kg}^{-1}$} \\
\hline & ${ }^{238} \mathbf{U}$ & ${ }^{232} \mathrm{Th}$ & ${ }^{40} \mathbf{K}$ \\
\hline Chittagong [Chowdhury et al., 1999] & 35 & 60 & 438 \\
\hline Pabna [Roy et al., 2001] & 33 & 47 & 449 \\
\hline Dhaka [ Miah et al., 1998] & 33 & 55 & 574 \\
\hline $\begin{array}{l}\text { Nine southern districts [Chowdhury et al., } \\
\text { 2006] }\end{array}$ & 42 & 81 & 833 \\
\hline Jessore [Kabir et al., 2009] & 48 & 53 & 481 \\
\hline Sitakunda [Rahman et.al., 2012] & 31 & 62 & 467 \\
\hline Kuakata Sea Beach [Islam et al.,2012] & 29 & 91 & 875 \\
\hline Cox’s Bazar [Alam et al., 1999] & 19 & 37 & 458 \\
\hline Sylhet [Miah et al.,2012] & 55 & 125 & 497 \\
\hline Rangpur [Hamid et al.,2002] & 87 & 140 & 1844 \\
\hline Lalmonirhat [Hamid et al.,2002] & 93 & 152 & 1951 \\
\hline Kurigram [Hamid et al.,2002] & 98 & 167 & 2168 \\
\hline Barendra region (present study) & 36.7 & 59.7 & 283 \\
\hline Mining region (present study) & 37.1 & 56.9 & 344 \\
\hline
\end{tabular}

The results show that the $\mathrm{H}_{\mathrm{ex}}$ values from all soil samples are below the limit of unity, meaning that the radiation dose is below the permissible limit of $1 \mathrm{mSv} \cdot \mathrm{y}^{-1}$ recommended by ICRP 60 [10]. This is displayed in Fig 3 (c). The Annual Effective Dose Equivalent $\mathrm{D}_{\text {eff }}$ from outdoor terrestrial gamma radiation was estimated by taking into account the conversion coefficients from absorbed dose in air to effective dose and the outdoor occupancy factor.
The Annual Effective Dose Equivalent $\mathrm{D}_{\text {eff }}$ for the Barendra region in this study vary from 70.3 to $88.5 \mu \mathrm{Sv} . \mathrm{y}^{-1}$, with mean value of $79.6 \mu \mathrm{Sv}^{-y^{-1}}$ and for the Mining region it varies from 68.4 to 99.4 $\mu \mathrm{Sv} . \mathrm{y}^{-1}$, with mean value of $80.8 \mu \mathrm{Sv} . \mathrm{y}^{-1}$, which is similar with the worldwide effective dose of 80 $\mu$ Sv. ${ }^{-1}[9]$. The values are graphically depicted in Fig 3(d).

Table 3. Comparison of Average activity concentration of ${ }^{238} \mathrm{U},{ }^{232} \mathrm{Th}$ and ${ }^{40} \mathrm{~K}$ in soil samples of different countries with the present study.

\begin{tabular}{|l|c|c|c|}
\hline \multirow{2}{*}{ Countries } & \multicolumn{3}{|c|}{ Average activity concentration in Bq.kg-1 } \\
\cline { 2 - 4 } & ${ }^{\mathbf{2 3 8}} \mathbf{U}$ & ${ }^{\mathbf{2 3 2}} \mathbf{T h}$ & ${ }^{\mathbf{4 0}} \mathbf{K}$ \\
\hline Denmark [UNSCEAR, 2000] & 17 & 19 & 460 \\
\hline Poland [UNSCEAR, 2000] & 26 & 21 & 410 \\
\hline Greece [UNSCEAR, 2000] & 25 & 21 & 360 \\
\hline Romania [UNSCEAR, 2000] & 32 & 38 & 490 \\
\hline Spain [UNSCEAR, 2000] & 32 & 33 & 470 \\
\hline Luxembourg [UNSCEAR, 2000] & 35 & 50 & 620 \\
\hline Saudi Arabia [Alaamer,2008] & 15 & 11 & 225 \\
\hline Nigeria [Okeyode et al., 2010] & 14 & 19 & 896 \\
\hline Turkey [Bozkurt et al., 2007] & 21 & 25 & 298 \\
\hline Pakistan [Akhtar et al., 2004] & 30 & 56 & 642 \\
\hline West Bank-Palestine [Dabayneth et.al., & 69 & 48 & 630 \\
\hline Worldwide average [UNSCEAR, 2000] & 35 & 30 & 400 \\
\hline Barendra region (present study) & $\mathbf{3 7}$ & $\mathbf{6 0}$ & $\mathbf{2 8 3}$ \\
\hline Mining region (present study) & $\mathbf{3 7}$ & $\mathbf{5 7}$ & $\mathbf{3 4 4}$ \\
\hline
\end{tabular}


Table 4. Radium Equivalent Activity, Dose Rate, External Hazard Index and Annual Effective Dose Equivalent for samples in both regions.

\begin{tabular}{|c|c|c|c|c|c|}
\hline Locations & $\begin{array}{c}\text { Sample } \\
\text { codes }\end{array}$ & $\begin{array}{c}\text { Radium Equivalent } \\
\text { Activity, } \mathbf{R a}_{\mathrm{eq}}(\mathrm{Bq} / \mathrm{kg})\end{array}$ & $\begin{array}{c}\text { Absorbed } \\
\text { Dose Rate, D } \\
(\text { nGy/h) } \\
\end{array}$ & $\begin{array}{c}\text { External } \\
\text { Hazard Index, } \\
\mathbf{H}_{\mathrm{ex}} \\
\end{array}$ & $\begin{array}{c}\text { Annual Effective } \\
\text { Dose, } D_{\text {eff }}\left(10^{-6}\right. \\
\text { Sv })\end{array}$ \\
\hline \multirow{11}{*}{ 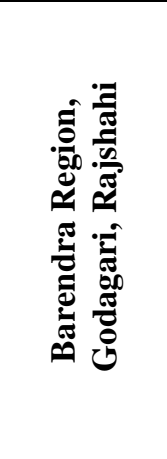 } & RGMM & 156.3 & 70.6 & 0.43 & 86.6 \\
\hline & RGSM & 125.2 & 57.3 & 0.34 & 70.3 \\
\hline & RGCB & 134.5 & 61.4 & 0.37 & 75.3 \\
\hline & RGDG & 133.3 & 61.6 & 0.37 & 75.6 \\
\hline & RGKH & 141.8 & 65.2 & 0.39 & 79.9 \\
\hline & RGAT & 158.3 & 72.2 & 0.43 & 88.5 \\
\hline & RGBP & 135.6 & 62.4 & 0.37 & 76.5 \\
\hline & RGJB & 144.7 & 66.1 & 0.40 & 81.0 \\
\hline & RGBM & 139.5 & 63.6 & 0.38 & 78.0 \\
\hline & RGKP & 151.0 & 68.9 & 0.41 & 84.5 \\
\hline & RGMD & 140.6 & 64.8 & 0.39 & 79.4 \\
\hline \multicolumn{2}{|c|}{ Mean } & 141.9 & 65.0 & 0.39 & 79.6 \\
\hline \multirow{11}{*}{ 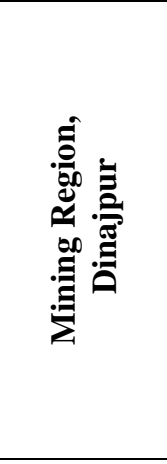 } & DFSA & 139.6 & 63.5 & 0.38 & 77.8 \\
\hline & DFTP & 143.8 & 68.3 & 0.40 & 83.80 \\
\hline & DFCP & 143.1 & 66.4 & 0.39 & 81.4 \\
\hline & DPCM & 180.9 & 81.1 & 0.49 & 99.4 \\
\hline & DPSM & 121.8 & 55.8 & 0.33 & 68.4 \\
\hline & DPVP & 135.5 & 62.3 & 0.37 & 76.4 \\
\hline & DHHL & 131.7 & 61.5 & 0.36 & 75.4 \\
\hline & DBSA & 153.7 & 72.1 & 0.42 & 88.3 \\
\hline & DBJN & 126.3 & 60.0 & 0.35 & 73.5 \\
\hline & DNSP & 143.5 & 66.7 & 0.39 & 81.8 \\
\hline & DNSA & 147.5 & 67.8 & 0.40 & 83.1 \\
\hline \multicolumn{2}{|c|}{ Mean } & 142.5 & 65.9 & 0.39 & 80.8 \\
\hline
\end{tabular}

\section{CONCLUSIONS}

The activity concentrations of ${ }^{238} \mathrm{U}$ and ${ }^{232} \mathrm{Th}$ in the samples of the two regions are found to be similar; the ${ }^{40} \mathrm{~K}$ concentration of Mining region is slightly higher. The ${ }^{238} \mathrm{U}$ and ${ }^{232} \mathrm{Th}$ concentrations are, in general, similar with those in most districts in Bangladesh except in Sylhet and in the high radiation background of Rangpur, Lalmonirhat and Kurigram districts. The ${ }^{40} \mathrm{~K}$ concentrations in the samples of the present study are lower than those in the samples of all other districts in Bangladesh. The average ${ }^{238} U$ concentration in the samples of the present study is similar with the world average. On the other hand, the average ${ }^{232} \mathrm{Th}$ concentration is double the world average.

The average ${ }^{40} \mathrm{~K}$ concentration is lower than the world average. No ${ }^{137} \mathrm{Cs}$ is found in the samples of the present study. It seems that there is no fresh nuclear fallout in places under study. The Radium Equivalent Activity $\mathrm{Ra}_{\mathrm{eq}}$ due to the radionuclides in the samples has been estimated. This value is found to be about 2.5 times less than the permissible maximum value of $370 \mathrm{~Bq} \cdot \mathrm{kg}^{-1}$. The Absorbed dose rate $\mathrm{D}$ estimated from the soil activity of the tow regions are similar, but slightly greater than the worldwide mean value $60 \mathrm{nGy} \cdot \mathrm{h}^{-1}$. The External Hazard Index $\mathrm{H}_{\mathrm{ex}}$ of the two regions is found to be 0.39 which is much below the maximum limit of unity. The Effective Dose Equivalents $D_{\text {eff }}$ of the two regions under study is found to be $80 \mu \mathrm{Sv} \mathrm{y}{ }^{-1}$ which is similar with the worldwide effective dose of $80 \mu \mathrm{Sv} \mathrm{y}^{-1}$. The natural radioactivity in the two regions poses no health-hazards to the population there.

\section{REFERENCES}

1. International Atomic Energy Agency, 2003. Extent of Environmental Contamination by Naturally Occurring Radioactive Material (NORM) and Technological Options for Mitigation, Technical Reports Series No.419, IAEA, Vienna.

2. National Council on Radiation Protection and Measurements, 1975. Natural Background 
Radiation in the United States, NCRP Report No.45. NCRP, Washington, D.C.

3. World Nuclear Association, [Updated August 2011].Radiation and Nuclear Energy. Retrieved from: http://www.worldnuclear.org/info/inf30.html.

4. International Atomic Energy Agency, 2005. Proceedings of an international Conference on Naturally Occurring Radioactive Materials (NORM IV), IAEA-TECDOC-1472, Poland: IAEA, Vienna.

5. United Nations Scientific Committee on the Effects of Atomic Radiation (UNSCEAR), 2000. Sources and Effects of Ionizing Radiation, Report Vol.1 to the General Assembly, with scientific annexes, United Nations Sales Publication, UN, New York, USA.

6. International Atomic Energy Agency, 1989. Measurement of radio-nuclides in food and the environment Technical Report Series No. 295, IAEA, Vienna.

7. United Nations Scientific Committee on the Effects of Atomic Radiation (UNSCEAR), 1988. Exposure from natural sources of radiation, Report to the General Assembly, United Nations Sales Publication UN, New York, USA.

8. Hamid B N, Chowdhury M I, Alam M N and Islam M N, 2002. Study of Natural Radionuclide Concentrations in an Area of Elevated Radiation Background in the Northern Districts of Bangladesh.Radiation Protection Dosimetry, Vol: 98(2): 227-230.

9. Miah A, Miah M M H, Kamal M, Chowdhury M I, Rahmatullah M, 2012. Natural Radioactivity and Associated Dose Rates in Soil Samples of Malnichera Tea Garden in Sylhet District of Bangladesh. Journal of Nuclear and Particle Physics, 2(6):147-152. doi: 10.5923/j.jnpp.20120206.03

10. International Commission on Radiological Protection, 1991. Radiation Protection, ICRP Publication 60. Pergamon Press, Inc.,Elmsford, NY.

11. Chowdhury M I, Alam MN., Hazari SKS., 1999. Distribution of Radionuclides in the River Sediments and Coastal Soils of
Chittagong, Bangladesh and Evalution of the Radiation Hazard.Applied Radiation and Isotope; Vol: 51: 747-755.

12. Roy S., Hoque A., Begum M., 2001. Distribution of 137Cs and Naturally Occurring Radionuclides in Soil at Sites of the Roopur Nuclear Power plant., Nuclear Science and Applications, Vol: 10 (1,2): 33-38.

13. Miah F K, Roy S., Touhiduzzaman M., Alam B. 1998. Distribution of Radionuclides in soil samples in and arround Dhaka city. App. Radiat.Isot, Vol: 49(1,2): 133-137.

14. Chowdhury M.I., Kamal M., Alam M.N., Yeasmin S and Mostafa M N., 2006. Distribution of naturally occurring radionuclides in soils of the southern districts of Bangladesh. Radiation Protection Dosimetry, Vol: 118(1): 126-130.

15. Kabir K A., Islam S M., Rahman M M., 2009. Distribution of Radionuclides in Surface Soil and bottom Sediment in the District of Jessore, Bangladesh and Evaluation of Radiation Hazard. Journal of Bangladesh Academy of Sci ences, Vol.:33(1): 117-130.

16. Rahman M M., Islam A T., Kamal M., Chowdhury M I. 2012. Radiation hazards due toterrestrial radionuclides at the coastal area of Ship Breaking Industries, Sitakunda, Bangladesh.Science Journal Publication, Vol: 20(2): 6 .

17. Islam K M N., Paul D., Bhuiyan M R., Akter A., Neher B., Islam S M A, 2012. Study of Environmental Radiation on Sand and Soil Samples from Kuakata Sea Beach of Patuakhali. Journal of Environmental Protection, Vol.3:1078-1084 doi:10.4236/jep.2012.39126.

18. Alam M N., Chowdhury M I., Kamal M., Ghose S., Islam M N., Mustafa M N., Miah M M H., Ansary M M., 1999. The 226Ra, 232Th and $40 \mathrm{~K}$ activities in beach sand minerals and beach soils of Cox's Bazar, Bangladesh. Journal of Environmental Radioactivity, Vol: 46(2): 243-250.

19. Alaamer A S., 2008. Assessment of Human Exposures to Natural Sources of Radiation in Soil of Riyadh, Saudi Arabia. Turkish Journal of Engineering \& Environmental Sciences, Vol: 32: 229-234. 
20. Okeyode I., Oluseye A., 2010. Studies of the Terrestrial Outdoor Gamma Dose Rate Levels in Ogun-Osun River Basins Development Authority Headquarters, Abeokuta, Nigeria. Physics International, Vol. 1(1): 1-8. doi:10.3844/pisp.2010.1.8.

21. Bozkurt A., Yorulmaz N., Kam E., Karahan G., Osmanlioglu A., 2007. Assessment of Environmental Radioactiv- ity for Sanliurfa Region of Southeastern Turkey. Radiation Measurements, Vol: 42(8): 1387-1391. doi:10.1016/j.radmeas.2007.05.052.

22. Akhtar N., Tufail M., Choudhry M A., Orfi S D., Waqas M., 2004. Radiation Dose from
Natural and Manmade Ra- dionuclides in the Soil of Niab, Faisalabad, Pakistan. The Nucleus, Vol: 41(1-4): 27-34.

23. Dabayneh K M., Mashal L A., Hasan F I., 2008. Radio- activity Concentration in Soil Samples in the Southern Part of the West Bank, Palestine. Radiation Protection Dosimetry, Vol: 131(2): 265-271. doi:10.1093/rpd/ncn161.

24. Dragovic, S. Jankovic L. and Onjia, A., 2006. Assessment of Gamma Dose Rate from Terrestrial Exposure in Serbia and Montenegro. Radiation Protection Dosimetry; Vol: 121 (3): 297-302. 